\title{
Myths, Schooling, and the Practice of Librarianship
}

\section{Charles R. Martell}

Myths, institutionalized values, and the uncritical acceptance of any one system of thought severely limit the process of objective evaluation. Problem identification, problem solving, and the generation of alternative courses of action may be circumscribed by the narrowness of perspective that results. Schools help to sustain myths and, in this role, act as instruments of social reproduction. As a consequence, underlying social, institutional, and economic value structures may be left unexamined. An understanding of the role educational institutions play in the creation and perpetuation of myths may allow us to demystify the library and library education. In this article six myths are proposed. Each is discussed. A key issue is the process through which these myths inhibit the responsiveness of our profession to user needs. Through the examination of the six myths it may be possible to shed additional light on the search for equity, objectivity, and commitment to service.

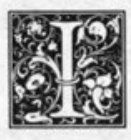

$n$ the early 1970 s a series of critics rallied against the fragmentation that typifies life in our industrial-bureaucratic society.

Few institutions were ignored. A group that included Charles Silberman, Jonathan Kozol, and Amitai Etzioni aimed its sallies at the American educational system, one of our most venerable institutions. Silberman examined American education and "pronounced it joyless, mindless, barren. ${ }^{\prime \prime}$ Etzioni was no kinder and characterized schools as "best suited to preparing indifferent cogs for an industrial bureaucratic machine, that is, at best, to be part of yesterday's world..$^{\prime 2}$ The words were harsh. They bordered on affrontery. Nevertheless, a challenge was presented. No one likes to be categorized as an indifferent cog.

Many of us view schools with hope. We hope that what we have learned will contribute to personal accomplishment and a sense of self-fulfillment. We hope that our children can avoid the mistakes that we have made. What degree of truth then ex- ists in the taunts of these educators?

This question had special meaning to me a decade ago as I was preparing to graduate from library school. In school I had formulated a set of beliefs about the profession of librarianship that provided a clear sense of purpose and acted as motivating influences. They were:

- Librarianship has significant growth potential.

- Professional roles are inadequately structured.

- Information is a critical resource.

- Libraries are relatively insensitive to the information needs of users.

- Libraries need to be redesigned.

- New technologies will lead to tremendous changes in libraries.

- Libraries are not change oriented.

The professional model seemed well suited to assist librarians in coping with these anticipated changes. The key elements in this process were professional autonomy (freedom) and objective evaluation (knowledge). Freedom and knowledge would lead to responsible action to

Charles R. Martell is associate university librarian for public services at California State University, Sacramento 95819. 
change libraries for the better. However, lurking in the rhetoric of the critics was an uncomfortable observation. "Guiding modern social life and interpersonal behavior is a destructive system of institutionalized values which determine how one perceives one's needs and defines instruments for their satisfaction. ${ }^{13}$

The critics suggested that (1) bureaucracies constrain autonomy (freedom) and (2) knowledge may be based on false or inaccurate perceptions of reality. When all eyes see the same message and when all ears hear the same tune, imagination is smothered and value conformity becomes an accepted social characteristic. "Once we are enmeshed in the magical resonance of the tribal echo chamber, the debunking of myths and legends is replaced by their religious study. Within the consensual framework of tribal values, there will be few if any rebels who challenge the tribe itself. ${ }^{\prime 4}$

\section{SCHOOLING}

The railings of the radical educators are no longer topical. Generally we have answered their criticisms by turning aside. Nevertheless, a few scholars did pick up the challenge. A steady progression of books and articles has appeared on the subject of schooling in America. ${ }^{5}$ No longer is it unfashionable among educators to demonstrate that schools act as instruments of social reproduction. From this perspective the primary function of the school system is to transmit intact dominant cultural, institutional, and social values. Social, economic, and political inequities are left unexamined.

Recently the schooling-in-America debate has centered on the degree and consequences of the process of social reproduction. The rhetoric has become more sophisticated. The Marxist/capitalist diatribes that sparked earlier controversies now seem quaint. Changing political systems and the complex interdependencies among nations in the economic sphere mandate new forms of intellectual development. These forms should allow individuals to follow the intricate interplay of forces without being ensnared by overly simplistic or dominant cultural para- digms. Unfortunately, as Thomas Popkewitz suggests, traditional scholarly practices may impede this development. "Far from being neutral, social science is an act of social affiliation and commitment. By distorting the social nature of inquiry, the practice of social science can be transformed into a mechanism of mystification and ideology.",6

Mystification is a concept that appears regularly in the writings of many observers of institutional life. Usually it is depicted as a force that disguises reality. Myths shroud the presidency. Cost overruns for weapon systems are tolerated because of the mythlike assumptions that the citizenry has toward the nation's defense. The value of "learning" is elevated to mythic proportions by educators because their schools cannot meet basic cost/ benefit criteria. Libraries emphasize their role at the center of our intellectual lives, while graduating students note with pride their ability to navigate the shoals of intellectual life without once using the library. Not too many years ago an American automotive manufacturer sought to convince us that what was good for General Motors was good for America. Institutions cloaked in such myths can often avoid close public scrutiny regarding the value of the products and services that they provide while promoting fiscal support and increasing the legitimacy that society accords them.

Since schools tend to mirror dominant cultural, institutional, and social values, myths that incorporate these values are easily transmitted to each succeeding generation of students. One result is frequently the development of an unquestioning and uncritical attitude toward the status quo and its underlying value structure. Chris Argyris finds that institutions create complex, interlocking norms to foster these attitudes. "You cannot openly confront norms that tell you not to confront policies and objectives," is but one example used by Argyris. ${ }^{8}$

John Meyer and Brian Rowan describe how institutionalized rules relating to professions, programs, and technologies are incorporated by the organization and function as myths. ${ }^{9}$ Under this cloak the 
rules are highly resistant to change. This occurs even if the rules have only a minor relationship to prevailing social behavior. For example, the structure of decisionmaking processes within organizations often bears little relationship to democratic practices or the search for equity.

By stressing ceremonial conformity the organization may seek external validation without reference to internal criteria for efficiency. "In place of coordination, inspection, and evaluation, a logic of confidence and good faith is employed. ${ }^{\prime 10}$ The public may see only a carefully structured image of the organization. Through their management of information, organizational leaders can idealize, minimize, exaggerate, or distort actual events. The purpose is usually to project a positive image in order to increase legitimacy, stability, and resources. These are important objectives, especially for institutions in environments where survival has become the underlying organizational principle:

Organizations under attack in competitive environments-small farms, passenger railways, or Rolls Royce-attempt to establish themselves as central to the cultural traditions of their societies in order to receive official protection. ${ }^{11}$

Rigid adherence to ceremonial conformity limits the incentive of organizational members to respond in a direct or forceful way to changes in user needs. In libraries the result is frequently the creation of a serious gap between service goals and the user-oriented behavior of the institution. This may be self-serving since it reinforces the requirement for professionals to bridge the gap. Simultaneously, and conveniently, the myths help to create an atmosphere of user expectation about how libraries should perform. Indeed, the expectation is usually a litany of traditional library services. The tendency of some organizations to decouple the formal structure from work activities can have two other major side effects. First, organizational members may be unaware of the myths and the degree to which they cloud individual perceptions of reality. Second, individuals may feel powerless to propose changes in light of the stigma that they would experience from those who uphold the myths.

Myths, institutionalized values, and the uncritical acceptance of any one system of thought severely limit the process of objective evaluation. Problem identification, problem solving, and the generation of alternative courses of action may be circumscribed by the narrowness of perspectives that results. What steps can be taken to demystify the library and its handmaiden, the library school?

\section{LIBRARIES AND MYTHS}

A number of steps are taken in this article. Six myths are proposed. Each is discussed. A key issue is the process through which these myths inhibit the responsiveness of our profession to user needs. Through the examination of the six myths it may be possible to shed additional light on the search for equity, objectivity, and commitment to service.

\section{Myth \#1: Libraries Are at the Center of Our Intellectual Lives}

For the existence of a library, the fact of its existence, is, in itself and of itself, an assertion-a proposition nailed like Luther's to the door of time. By standing where it does at the center of our intellectual lives-with its books in a certain order on its shelves and its cards in a certain structure in their cases, the true library asserts that there is indeed a "mystery of things." (Archibald MacLeish, Former Librarian of Congress) $^{12}$

Library schools promote the myth of the library. Students are fed the Grimms' fairy tale of librarianship. The library is depicted as a healthy institution rather like the downtown department store. It is pleasant to bask in the glow of our admirers. Savor, for example, the love that Archibald MacLeish showers on our institution. The myth is dispelled once we recognize that the library exists in a highly competitive world.

The myth still has great appeal. It contains elements of truth. The myth, however, tends to isolate and buffer the library from critical evaluation both by those within and those external to the library. 
Legitimacy and survival are strengthened if the basic premise is accepted.

MacLeish emphasizes the fact of the library's existence almost as if that were a primary purpose or sufficient justification. The imagery is static. Intellectual life, on the other hand, is often characterized by turbulence and change. Ortega y Gasset, a Spanish philosopher and librarian, appreciated the nature of this struggle between the static and the dynamic. "The man who discovers a new scientific truth has previously had to smash to atoms almost everything he had learnt, and arrives at the new truth with hands bloodstained from the slaughter of a thousand platitudes." $" 13$

Intellectual life centers first within one's own being and not in an amorphous institution. We, as individuals, give libraries their life. As we learn and distill from the latent treasures housed in libraries, we transform the static store of information into a vital and meaningful reality. The impersonal values of bureaucratic institutions should not be the mainspring of our spirit or the spokesperson for our philosophy.

\section{Myth \# 2: The Book Is Sacred}

How can we analyze objectively the nature of a problem that brings out so many hostile emotions on either side, for whatever sincere and/or self-serving purposes? Part of the problem, I suspect, is a widespread cultural belief in the sacredness of the book, the printed word, and even the written word. (David Stam, Director, the Research Libraries of the New York Public Library) ${ }^{14}$

The analysis of myths offers fascinating opportunities for the use of imagination. For example, is it possible that works such as the Holy Scriptures contributed to the development of a "book is sacred" myth? The high esteem in which knowledge is held among various peoples and civilizations may have allowed books, a vehicle containing knowledge in static form, to benefit from a content-to-vehicle esteem switch.

Many myths serve a valuable purpose. Life has its mysteries. Even as one strives to maintain a detached objectivity, aware- ness of the limitations of the human mind and the inescapable links that each of us share unconsciously with our environment must be admitted. Acceptance of myths and their value should not, however, hinder us from demonstrating how myths can constrain action to improve these same environments. Three problems can be mentioned in connection with the myth of the book:

- The vehicle (book) rather than the content (information) has ascendant value.

This limits responsiveness to user needs.

- Once acquired, each book tends to be given an equal value. This practice supplements a strong professional ethic that discourages librarians from transmitting to users value judgments about the quality, content, or usefulness of specific books.

- The book and other printed works are given a transcendent value over other media. This has impeded the adoption and effective use of other media in libraries.

From this perspective libraries should move away from a static focus on the book and should be reoriented to give primary emphasis to the usefulness of the information (i.e., the information transfer exchange). This would increase the relevance of librarians and would position us to make more valuable contributions to the knowledge society.

\section{Myth \# 3: Libraries Are Responsive to the Information Needs of Their Various Publics}

The traditional paradigm of professionalism encourages a static condition which is incompatible with the dynamism inherent in a truly client-centered (including non-user clients) professional orientation. (C. James Schmidt, Vice President, Research Libraries Group) ${ }^{15}$

Outsiders have found libraries seriously at fault in their basic design for user services. ${ }^{16}$ Others indicate that users are intentionally isolated from the workings of the library, which moves with a momentum of its own. ${ }^{17}$ Insiders have found the profession to be self-serving with a tendency to ignore and discourage interac- 
tion with the user community. ${ }^{18}$ The Meyer and Rowan model of organizational decoupling in which the formal structure is purposefully separated from work activities would explain the buffering of work units from environmental influences, thereby isolating the institution from the user. The card catalog has been described as a major technology almost entirely buffered from direct user input. This results partially from the tendency to treat users as problems, as sources of disorder rather than as sources of direction. This provides a convenient excuse to avoid close interaction.

Roger Morris boasts: "Institutions best serve those who seek them out. ${ }^{\prime 19} \mathrm{He}$ warns librarians who view their role as having important teacher-like qualities to "tread lightly if at all." ${ }^{\prime 20}$ Religion and genetic coding are used to support the righteousness of yet another myth standing in our path to relevance. "By and large, the librarian and the teacher have respected each other's turf as religiously as if the theory of territorial imperative was permanently etched in their genetic coding. ${ }^{\prime 21}$ Our profession stresses function. Yet our art, our spirit as librarians, should rest on communication.

Bibliographic instruction has made strong inroads since 1973 when Morris made his remarks. Nevertheless, many reference librarians still fail to view bibliographic instruction as an integral component of reference service. Accordingly, the position of bibliographic instructor has usually been established as a staff and not a line function in order to ease the diffusion of this innovation to a hesitant staff.

Some librarians believe that a basic conflict exists between user needs and professional services. Studies have been conducted. Reports have been published. Users have frequently been found mindless and shallow: they cannot understand the system. "Lack of persistence, lack of adequate bibliographic information, faulty and inadequate library search strategies, ignorance of library stock lay-out and sheer carelessness in searching . . . all take their toll and result in a volume of failure which would not be tolerated from li- brarians.,"22 This attitude is not uncommon. What it overlooks is the possibility that librarians may have developed faulty services and bibliographic tools. It overlooks the possibility that librarians may not only solve problems but create problems. The late Jesse $H$. Shera suggested that "library efficiency frequently consists of doing very well what need not be done at all." 23 The absence of a strong clientcentered orientation in the profession may be one sign of this pattern. ${ }^{24}$

\section{Myth \# 4: Objective Evaluation Is a Common Decision-making Practice in Libraries}

A library operates in a political environment and nearly all the really important decisions that are made at the highest levels have an overriding political component. (Richard DeGennaro, Director of Libraries, University of Pennsylvania) $^{25}$

Objective evaluation and the autonomy of librarians have been identified as key ingredients for meaningful change in the profession. However, if objective evaluation functions as a myth, the capacity of librarians to act responsively to environmental demands is seriously eroded.

User studies are a familiar type of objective evaluation. Over one thousand user studies have been conducted in the last twenty years. These studies represent an enormous human investment. In terms of change based on the findings, the results are marginal. In part, this occurs because of a widespread tendency to view the study as the end product and not as a prelude to action. While convenient, this practice destroys the will to act. The final judgment regarding the success of user studies and other similar forms of objective evaluation should be:

- What direct benefits do library users experience?

- How significant are the benefits?

- How long do the benefits last?

- How do the changes allow the library staff to provide improved direct services?

By demonstrating the value of the library in an "objective" manner, credibility is enhanced and confidence is gener- 
ated in the minds of relevant publics. Unfortunately, evaluation also has strong appeal as a public relations gesture. So library studies are often long on story and short on action. Initial staff expectations and commitment are high. It seems certain that the results of the study will lead to meaningful progress-things will get better. Months later, after the study has been completed, the major recommendations lie dormant and nothing has happened. The few changes are cosmetic, which only seems to increase the general sense of futility. This happens because decisions are often made to support the selfinterest-status, control, and power-of officeholders and dominant coalitions. ${ }^{26}$ The myth of objective evaluation permits this reality to be disguised.

Objective evaluation is often targeted to support predetermined positions. If the results of the evaluation do not conform to these positions it is a simple matter to accept only those recommendations that match particular positions, to change or massage the sample, to alter the underlying assumptions, to discredit the report, or to file without action. When wielded in this manner, as a political tool, the basic integrity of objective evaluation risks being undermined.

\section{Myth \# 5: The Professional Model of Librarianship Fosters Active Client-oriented Behaviors}

After our technological problems have been solved, libraries can turn to people and to people-oriented programs. (Martha Boaz, Former Dean, School of Library Science, University of Southern California) ${ }^{27}$

The power of every profession is based on (1) the value that society places on the perceived knowledge and skills of the professional and (2) the monopoly that society accords to those who possess this knowledge and skill. ${ }^{28}$ Once the monopoly is received, a shift often occurs so that the control of knowledge rather than knowledge itself becomes the primary goal. Control is maintained through the ability of the profession to accredit schools, to establish curricula, to certify, and to set standards. Our profession has acquired the right to perform these functions.

To preserve its authority a profession has a vested interest in creating a myth of expertise. This myth is developed in several ways:

- By increasing the legitimacy of professional activities through the creation of highly rationalized institutional rules.

- By withholding from the public access to the knowledge and skills that form the basis of professional power.

- By expropriating certain types of knowledge and functions (e.g., online database searching) in order to bring it within the professional's domain.

- By organizing so that society lacks the information necessary to evaluate the profession.

- By defining the appropriate types of services and programs, thereby molding user expectations to conform with internal performance norms.

Once the public accepts the myth of expertise, maintenance of the myth becomes relatively simple through accreditation (ritual) and certification (ceremony). "If librarians truly wish to work toward the best interests of their users, it is absurd to continue to advocate the old classic professionalism, which places users in a dependency relationship with librarians. ${ }^{\prime 29}$

\section{Myth \# 6: Library School Education Alone Provides a Sufficient Differentiation Between the Professional and Nonprofessional}

The school system today performs the threefold function common to powerful churches throughout history. It is simultaneously the repository of society's myths, the institutionalization of that myth's contradictions, and the locus of the ritual which reproduces and veils the disparities between myth and reality. (Ivan Illich, Educator) ${ }^{30}$

Higher education benefits individuals and society by "(1) creating membership categories, (2) legitimating the social rights and meanings attached to these groups, and (3) ritually certifying individuals as members." ${ }^{31}$ These symbolic actions are accomplished independently of any direct benefit schooling has on the 
student. Myths may therefore be created by colleges to demonstrate that their graduates possess certain intrinsic qualities resulting from their college experience. ${ }^{32}$

The primary feature transmitted by library schools is the enhancement of the potential ability to perform effectively a set of functional activities commonly referred to as professional work. The myths of schooling and expertise may intertwine in this context to strengthen one another, and obscure further the reality that each serves to disguise. Since library schools must produce students capable of carrying out the work required in libraries, they find it necessary to promote a value structure that mirrors the one internalized by librarians in the field.

Traditionally, library school students have not been taught to examine the professional model; they have been taught faith. Library school students have not been taught to evaluate the system of values on which the library as an organization is based; they have been taught deference. Library school students have not been taught to question the status differentials explicit in the formalized institutional arrangements-faculty vis-à-vis students, librarians vis-à-vis nonprofessionals; they have been taught to value the concept of expertise over the reality of equity. In their classic work, "Professionalism Reconsidered,' Mary Lee Bundy and Paul Wasserman state: "The responsibility for a lack of aggressive professional service in problem-solving terms must be laid at the door of professional education for librarianship. For the schools, with only rare exceptions, have failed to breed an appreciation for the subtleties or the potentialities of the professional role. ${ }^{\prime \prime 33}$

The product of library schools may not be a student with a mind questing for truth and a spirit dedicated to community service. Rather, forged through years of schooling to accept the blandishments of authority figures, the student may succumb and again abdicate his or her main source of hope-an inquiring mind and an active will. Blanche Prichard McCrum, characterized as a small giant in the history of American librarianship, wrote:

The verb to do is conjugated too well in libraries, the verbs to know and to be have all too little definite, effective consideration. ${ }^{34}$

\section{CONCLUSION}

As I have examined myths, my appreciation for their complexity and their role in our culture has grown. Now I have a sense of how they contribute to shared understandings. Schools play an important part in mythmaking through the process of social reproduction. They transmit myths and elaborate upon them. Not all myths. Only some. As children and as adults we may act on these myths as if they were truths. A harmless enactment? Not always.

How many of you remember from schooldays the crude stereotypes that perpetuated the myths of the red man or the black man or the yellow man? How we shuddered at the tales of massacre, the wanton consumption of firewater, the reckless sale of firearms, and the scalping of our yellow-haired champion of the West.

Let us choose our myths carefully-to elevate not to denigrate. In librarianship our myths may disguise the relationship between self-interest and user-interest. In librarianship our myths elevate the institution over the potential vitality that we possess as active forces for the transmission and creation of knowledge.

Knowledge, freedom through autonomy, and the will to act are the elements that we must use to see clearer and to serve better. We must challenge the myths that only serve to dwarf us.

\section{REFERENCES AND NOTES}

1. Christopher Lehmann-Haupt, "The Book That May Break the Knowledge Bank," New York Times (Oct. 8, 1970).

2. Amitai Etzioni, "Review of Crisis in the Classroom by Charles E. Silberman," Harvard Educational Review 41:97-98 (Feb. 1971). 
3. Herbert Gintis, "Toward a Political Economy of Education: a Radical Critique of Ivan Illich's Deschooling Society," Harvard Educational Review 42:72 (Feb. 1972).

4. Source unknown.

5. A number of major works focus on schooling and the process by which the schools reproduce or mirror dominant cultural and socioeconomic values. These are: Michael Apple, Ideology and Curriculum (Boston: Routledge \& Paul, 1979); Pierre Bourdieu and Jean-Claude Passeron, Reproduction in Education, Society, and Culture (London: Sage, 1977); Samuel Bowles and Herbert Gintis, Schooling in Capitalist America: Educational Reform and the Contradictions of Economic Life (New York: Basic Books, 1976); Henry A. Giroux, "Beyond the Correspondence Theory: Notes on the Dynamics of Educational Reproduction and Transformation," Curriculum Inquiry 10:225-47 (Fall 1980); Martin Carnoy and Henry Levin, The Limits of Educational Reform (New York: McKay, 1976); Gerald Grace, Teachers, Ideology and Social Control (Boston, Routledge \& Paul, 1978); Paul Willis, Learning to Labour: How Working Class Kids Get Working Class Jobs (Lexington, Mass.: Heath, 1977); and Michael Young, ed., Knowledge and Control (London: Collier-Macmillan, 1971). Henry Giroux's seminal article should help to reorient the schooling debate away from the overly simplistic view of most critics toward a view that recognizes "that reproduction is a complex phenomenon that not only serves the interests of domination but also contains the seeds of conflict and transformation" (p.243).

6. Thomas S. Popkewitz, "Paradigms in Educational Science: Different Meanings and Purpose to Theory," Journal of Education 162:29 (Winter 1980).

7. Institutional myths, their linkage to internal norms of desirability, and their resistance to change form the basis of the advice to organizational development (OD) specialists by David M. Boje and others, "Myth Making: a Qualitative Step in OD Interventions," Journal of Applied Behavioral Science 18:17-28 (1982). The dysfunctional attributes and related factors of myths are discussed by Kevin Harris, Education and Knowledge: The Structured Misrepresentation of Reality (Boston: Routledge \& Paul, 1979); Martin Burlingame, "Protecting Private Realities by Managing Public Symbols: Mystifications, Cover-up, and Martyrdom," Symposium on Power, Legitimacy and Secrecy in the Management of Schools and Classrooms, American Educational Research Association, Annual Meeting (1980); and William H. MacNeil, "The Care and Repair of Public Myth," Foreign Affairs 61:1-13 (Fall 1982).

8. Chris Argyris, "Double Loop Learning in Organizations," Harvard Business Review 55:116 (Sept.Oct. 1977).

9. John W. Meyer and Brian Rowan, "Institutionalized Organizations: Formal Structure as Myth and Ceremony," American Journal of Sociology 83:344 (Sept. 1977).

10. Ibid., p. 340 .

11. Ibid., p.348.

12. Archibald MacLeish, "The Premise of Meaning," The American Scholar 41:359 (Summer 1972).

13. Lawrence K. Frank, "Organized Complexities: A Rebuttal," in Toward Unification in Psychology, ed. Joyce Royce (Toronto: Univ. of Toronto Pr., 1970), p.242.

14. David Stam," 'Prove All Things: Hold Fast That Which is Good': Deaccessioning and Research Libraries," College \& Research Libraries 43:6 (Jan. 1982).

15. Gardner Hanks and C. James Schmidt, "An Alternative Model of a Profession for Librarians," College \& Research Libraries 36:176 (May 1975).

16. C. West Churchman, "Operations Research Prospects for Libraries: The Realities and Ideals," Library Quarterly 42:13-14 (Jan. 1972).

17. Gerard Salton, "On the Development of Libraries and Information Centers," Library Jourmal 95:3433-42 (Oct. 15, 1970).

18. Mary Lee Bundy and Paul Wasserman, "Professionalism Reconsidered," College \& Research Libraries 29:5-26 (Jan. 1968); Hanks and Schmidt, p.177.

19. Roger Morris, "Keep the Independent Student Independent," American Libraries 4:421 (July 1973).

20. Ibid., p.421.

21. Ibid., p.421.

22. A. D. Burnett, "Reader Failure: A Pilot Survey," in Research in Librarianship, 1:147 (1966).

23. "Profession Loses Revered Educator and Visionary, Jesse H. Shera: 1903-82," American Libraries 13:220 (Apr. 1982).

24. Charles Martell, The Client-Centered Academic Library: An Organizational Model (Westport, Conn.: Greenwood, 1983).

25. Richard DeGennaro, "Library Statistics and User Satisfaction: No Significant Correlation," Journal of Academic Librarianship 6:95 (May 1980).

26. Samuel B. Bacharach and Edward J. Lawler, Power and Politics in Organizations: The Social Psychol- 
ogy of Conflict, Coalitions, and Bargaining (San Francisco: Jossey-Bass, 1981), p.31.

27. Martha Boaz, "Some Current Concepts about Library Education," College \& University Libraries 33:18 (Jan. 1972).

28. Robert Reiff, "The Control of Knowledge: The Power of the Helping Professions," Journal of Applied Behavioral Science 10:453 (July-Aug.-Sept., 1974).

29. Brian Nielsen, "Teacher or Intermediary: Alternative Professional Models in the Information Age," College \& Research Libraries 43:188 (May 1982).

30. Ivan Illich, Deschooling Society (New York: Harper, 1972), p.54.

31. David H. Kamens, "Legitimating Myths and Educational Organization: The Relationship between Organizational Ideology and Formal Structure," American Sociological Review 42:208 (Apr. 1977).

32. Ibid., p.208.

33. Bundy and Wasserman, p.11.

34. Betty Ruth Kondayan, "Blanche Prichard McCrum: A Small Giant," Journal of Academic Librarianship 8:72 (May 1982). 

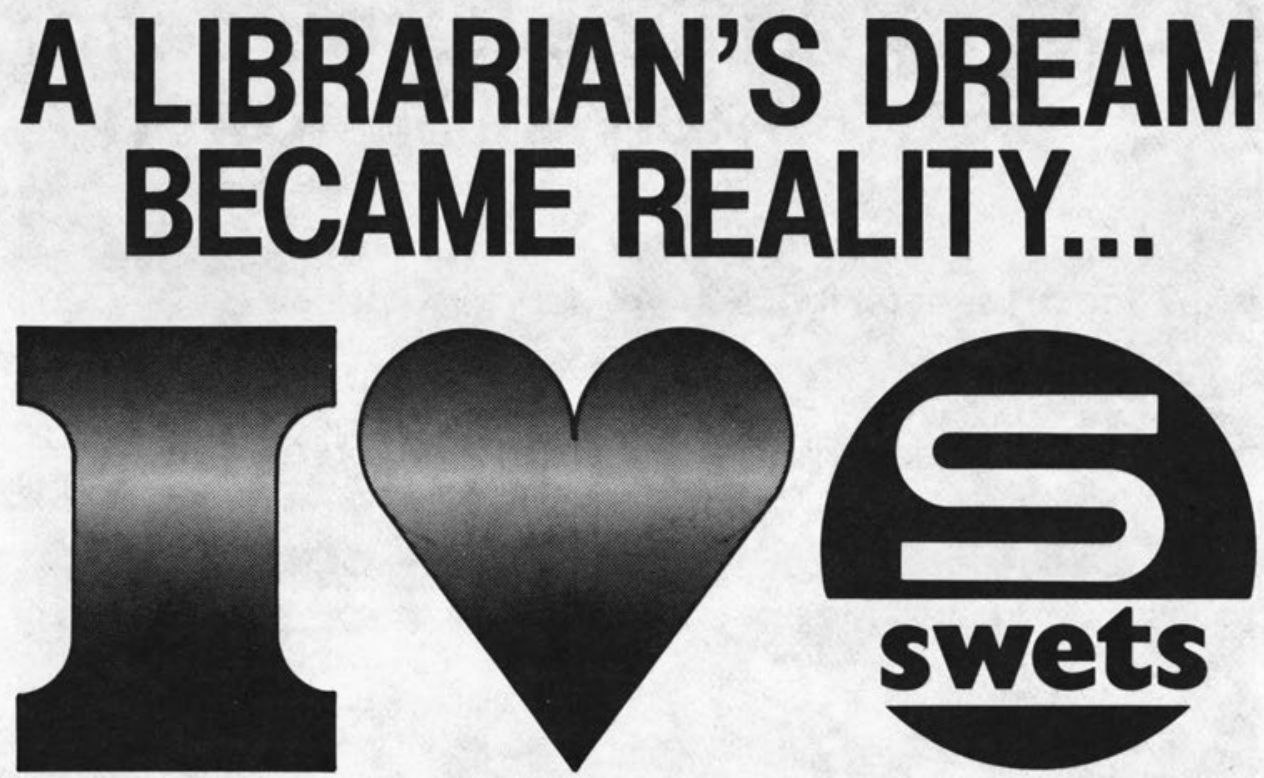

.... and there was plenty of time for the interesting aspects of library work ... the new year started with far less "European headache".

Notorious trouble titles arrived (air freighted) at regular intervals, securely packed and always accompanied by a packing slip with key numbers exactly according to the library's instructions (and of vital importance to the administration).

And ... believe it or not, an occasional missing issue (if any) had already been claimed with the publisher before it was noticed in the library ...

There was much more she could not remember after she woke up.... until she spotted the brochure she read the night before...

You are invited to share her dream. Ask for the same brochure, giving full details of the Swets FAST $^{\circ}$ system, an online system of controlled serial distribution.

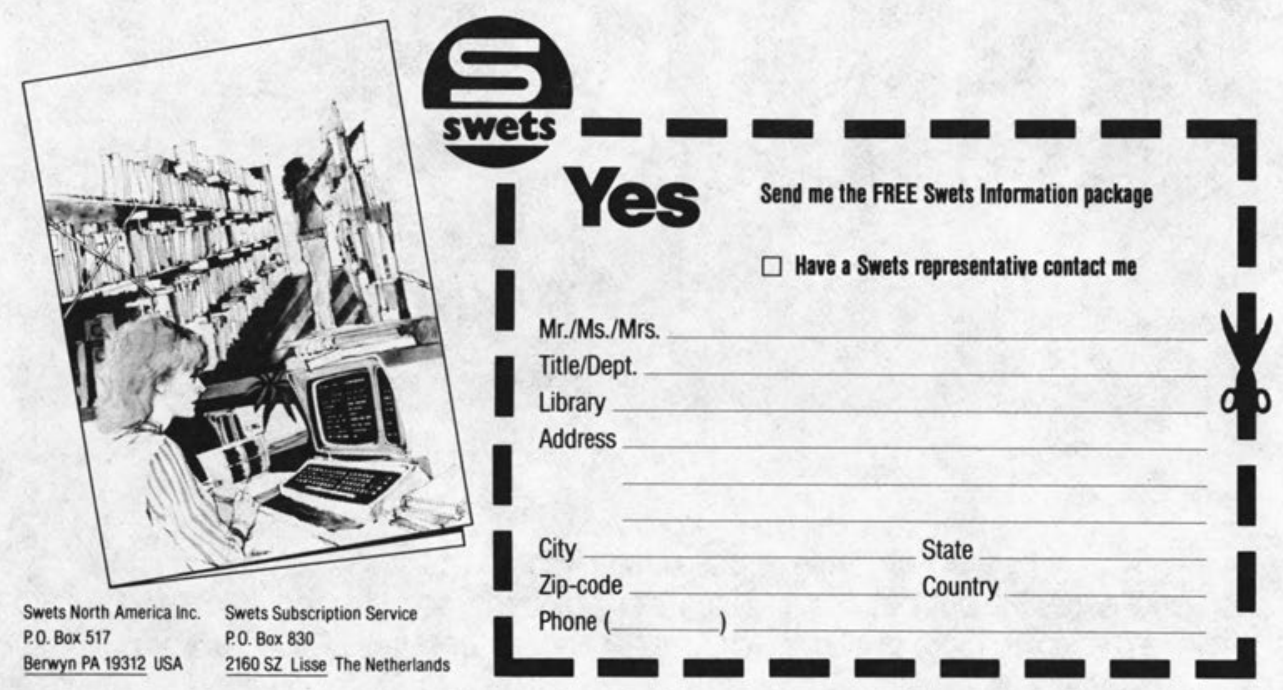




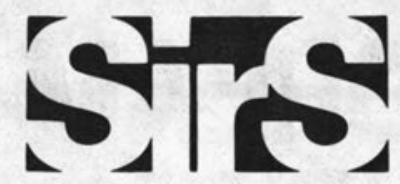

\section{A Prime Resource for Timely Information}

- 32 Social Issues for the '80s - Ideal for Reports

- Thousands of Articles

- Responsive to Individual Needs

- An Instant Vertical File

- Supplemented Annually

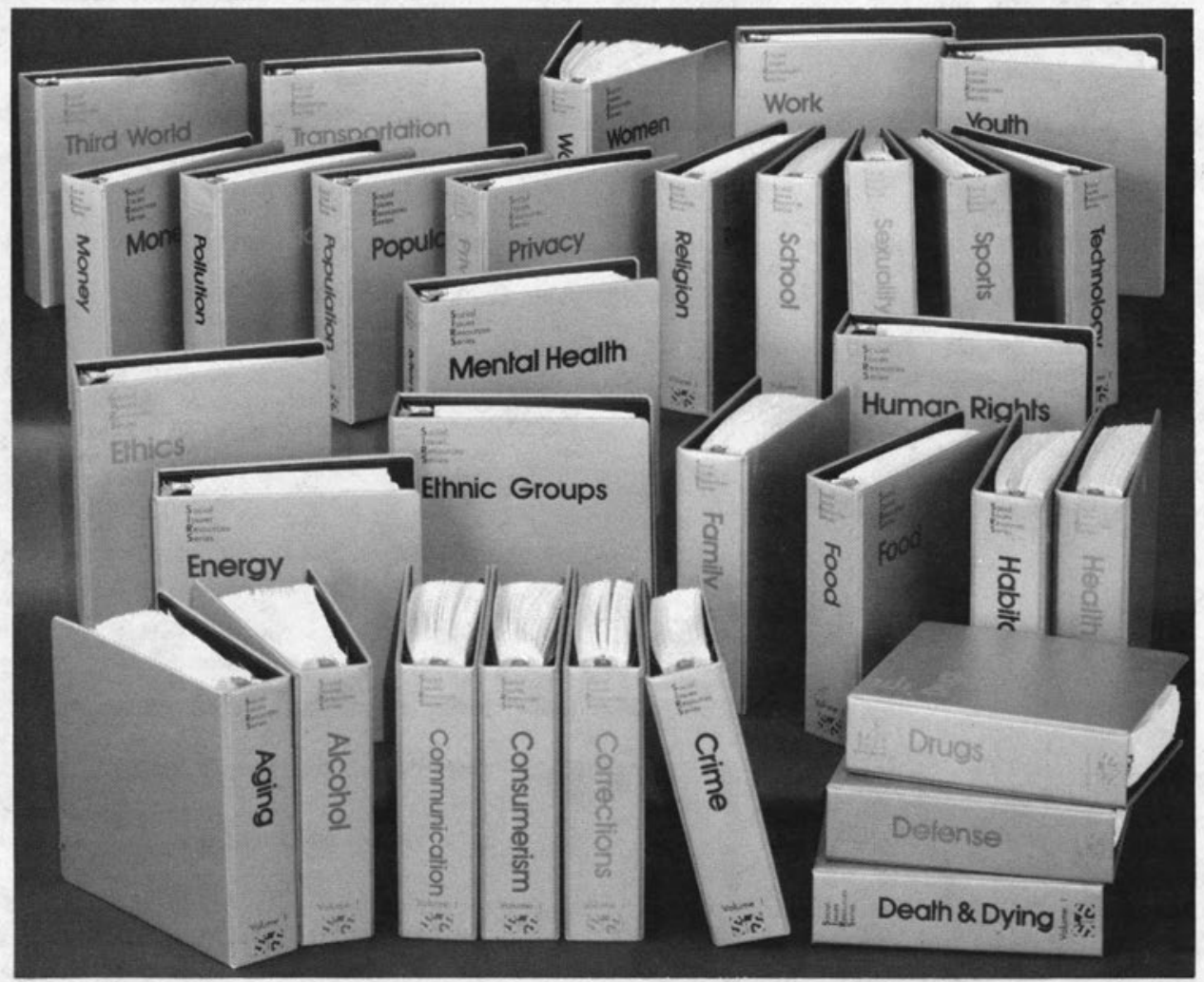

FOR INFORMATION, CONTACT:

SOCIAL ISSUES RESOURCES SERIES, INC. • P.O. BOX 2507, BOCA RATON, FLORIDA 33427 TELEPHONE: (305) 994-0079 TOLL FREE: 1-800-327-0513 (except AK, FL \& HI) 